\title{
A NATUREZA JURÍDICA DA RESPONSABILIDADE CIVIL DO ESTADO PELA DEMORA NA PRESTAÇÃO JURISDICIONAL
}

\section{THE LEGAL NATURE OF LIABILITY OF STATE FOR DELAY IN CONSTITUTIONAL PROVISION}

\author{
Jairo do Socorro dos Santos da Costa ${ }^{1}$ \\ Vinicius Pinheiro Marques ${ }^{2}$
}

\begin{abstract}
RESUMO
Diante da notória morosidade do Poder Judiciário, frente às necessidades de entrega da prestação jurisdicional de forma célere, razoável, eficiente e as divergências doutrinárias e jurisprudenciais, surge o questionamento, a saber, qual a natureza jurídica da responsabilidade civil do Estado em caso de demora na prestação da tutela judicial? Este trabalho permite inferir, em que pese entendimento jurisprudencial em contrário, que o dever do Estado em promover a justiça célere e eficiente se resume em ação positiva, cuja omissão é específica, o que atrai a responsabilidade civil objetiva.
\end{abstract}

Palavras-chave: Responsabilidade civil. Prestação jurisdicional. Celeridade. Razoável duração do processo. Morosidade.

\begin{abstract}
Given the notorious slowness of the judicial branch, opposite the delivery needs of adjudication swiftly, reasonable, efficient and the doctrinal and jurisprudential differences, the question arises, namely, what is the legal nature of the liability of the State in case of delay the provision of legal protection? This work allows us to infer, despite legal understanding to the contrary, that the duty of the State to promote the speedy and efficient justice comes down into positive action, the omission of which is specific, which attracts the objective liability.
\end{abstract}

Keywords: Civil liability. Adjudication. Speed. Average duration of the process. Slowness.

\footnotetext{
${ }^{1}$ Graduando do $10^{\circ}$ período do curso de Direito da Faculdade de Ciências Jurídicas de Paraíso do Tocantins FCJP, Bolsista PROUNI 100\% - 2010. Experiência na área de Direito, com ênfase em Direito pela Justiça Federal de $1^{\circ}$ grau - Região Tocantins, Ministério Público eDefensoria Pública, ambos em Paraíso do Tocantins. E-mail: djairinho@hotmail.com

${ }_{2}$ Mestre em Prestação Jurisdicional e Direitos Humanos pela Universidade Federal do Tocantins (UFT). Cursando Doutorado em Direito pela Pontifícia Universidade Católica de Minas Gerais (PUC Minas). Professor da Universidade Federal do Tocantins (UFT) e Faculdade de Ciências Jurídicas de Paraíso do Tocantins (FCJP). E-mail: viniciusmarques@ mail.uft.edu.br
} 


\section{INTRODUÇÃO}

[...] justiça atrasada não é justiça, senão injustiça qualificada e manifesta. Porque a dilação ilegal nas mãos do julgador contraria o direito escrito das partes, e, assim, as lesa no patrimônio, honra e liberdade. (BARBOSA, 1997, p. 40)

Com o Estado Democrático de Direito, a jurisdição passou a ser de domínio estatal, não mais se aplicando, salvo as exceções legais, a autodefesa e autotutela. Não obstante a Emenda Constitucional n 45/2004 trouxe significativas mudanças no texto constitucional, em especial assegurou que todos têm a garantia de um processo judicial e administrativo com razoável duração e meios que garantam a celeridade de sua tramitação. Tal inclusão no rol dos direitos fundamentais individuais representaria uma resposta à crise na prestação jurisdicional e as dificuldades na implementação dos direitos para a maioria da população.

Pela teoria geral da responsabilidade civil todo aquele que comete ato ilícito deve reparar o dano, sendo que o ato ilícito pode ser caracterizado por uma ação ou omissão frente a um dever legal. O Estado, enquanto pessoa jurídica de direito público, está sujeito a deveres. Nesse sentido, o problema central do artigo reside no seguinte questionamento: qual a natureza jurídica da responsabilidade civil do Estado que não cumpre com o seu dever constitucional de entregar uma prestação jurisdicional célere?

O objetivo geral da presente pesquisa é demonstrar que ante a omissão específica do Estado de entregar uma prestação jurisdicional célere surge o dever de reparar o dano de forma objetiva. Para alcançar tal desiderato foram traçados como objetivos específicos analisar os aspectos gerais das teorias sobre a responsabilidade civil do Estado para, num segundo momento, compreender os princípios constitucionais que incidem sobre o problema e, ao final, poder afirmar sobre a natureza jurídica da responsabilidade do estado pela demora da prestação jurisdicional.

Para a realização do presente artigo científico foi utilizada uma pesquisa qualitativa, com método dedutivo e com técnica de pesquisa documental, onde foram consultados livros, artigos científicos e legislação disponíveis em meio físico e eletrônico. 


\section{ASPECTOS GERAIS DA RESPONSABILIDADE CIVIL DO ESTADO}

O instituto da responsabilidade civil nem sempre foi instrumento material-legal do dever de indenizar, sendo que no Brasil foram visualizadas suas aplicabilidades com as ordenações Manuelinas e Filipinas a partir do ano de 1521 depois de cristo. Diante disso, se utilizou diretrizes do Código Napoleão de 1804, mesmo com a independência do território brasileiro de Portugal em 1822, que só se veio a instituir um Código Civil pátrio em 1916, mesmo com a ordem Constitucional de 1824 de criação de leis civis próprias.

O Código Civil de 1916, mesmo que empenhado por seus idealizadores, ainda foi muito abstrato quanto à responsabilidade civil. Já o código de 2002 trouxe maior definição sobre responsabilidade, seus requisitos e elementos de configuração do dever jurídico de indenizar.

Nessa mesma linha, no tocante à responsabilidade civil do Estado, também houve parâmetros de evolução trazidos por diversas mudanças, principalmente no elemento culpa. Cabe deixar claro, pois, que a forma de se abordar a responsabilidade civil do Estado é diferente da responsabilidade civil voltada ao direito privado. Da mesma forma, a responsabilidade civil do Estado é matéria estritamente vinculada aos direitos civil e administrativo, pois é o que se ver do artigo 37, § 6 da Constituição em vigor.

$\mathrm{Na}$ seara da responsabilidade civil do Estado pelos atos praticados em nome e em razão da administração da coisa pública, segundo Di Pietro (2010) as discursões traçam considerações antigas, a exemplo da teoria da irresponsabilidade do Estado pelos atos danosos omissivos ou comissivos. Tinha-se a ideia que o Estado era soberano e por isso não errava e nem podia ser responsável por danos. Nesse caso:

A teoria da irresponsabilidade foi adotada na época dos Estados absolutistas e repousava fundamentalmente na ideia de soberania: o Estado dispõe de autoridade incontestável perante o súdito; ele exerce a tutela do direito, não podendo, por isso, agir contra ele; daí os princípios de que o rei não pode errar (DI PIETRO, 2010, p. 644).

No tocante ao "domínio dos governos absolutistas negou-se a responsabilidade do Estado, secularizada na regra inglesa da infalibilidade real" 
(MEIRELLES, 2010, p. 681) e por sua evidente e irradiante desproporção legal, essa teoria foi ficando sem aplicabilidade jurídica. Se por um lado o Estado passa a ser o titular na tutela do direito, atraindo demasiadas responsabilidades, de certo ele deve responder por atos omissivos ou comissivos, lícitos ou ilícitos que causem dano a outrem, "mesmo porque, sendo pessoa jurídica, é titular de direitos e obrigações" (DI PIETRO, 2010, p. 644). Foi então que no século XIX a teoria da irresponsabilidade do Estado já não se via aplicável.

Então, assim como a pessoa física, a pessoa jurídica de direito público também tem responsabilidade civil. Seria ilógico eximir o ente estatal de reparar danos oriundos de suas atividades, sendo o detentor de grande aparato de conhecimento e domínio de tecnologia não pode deixar o ofendido ou lesado sem a devida reparação, ou, em casos como o de responsabilizar o agente que praticava o ato em nome e em razão da administração pública. Ora, o servidor público está vinculado ao poder hierárquico do Estado por meio da lei, o que faz daquele um instrumento de satisfação deste. Sem sentido, então, e grotesco responsabilizar tão somente a pessoa física por atos emanados do poder de subordinação, sem nenhuma forma de responsabilidade do poder público, conforme ensina Mello (2009):

\begin{abstract}
Demais disso, o princípio da irresponsabilidade do Estado era temperado em suas consequências gravosas pelos particulares pela admissão da responsabilidade do funcionário, quando 0 ato lesivo pudesse ser diretamente relacionado a um comportamento pessoal. É bem verdade, todavia, que a operatividade da solução, sobre se revelar insuficiente pela pequena expressão do patrimônio que deveria responder, era gravemente comprometida em sua eficácia pela existência de uma garantia administrativa dos funcionários (MELLO, 2009, p. 991).
\end{abstract}

Com razão, a irresponsabilidade civil do Estado passou, com suas fases evolutivas, para a responsabilidade com culpa, ou subjetiva. Consoante a isso, "a doutrina da irresponsabilidade está inteiramente superada" (MEIRELLES, 2010, p. 681). Portanto, não mais se aplica a teoria da irresponsabilidade civil do Estado, sendo certo que atualmente qualquer ato do ente estatal pode configurar dano e ser passível de reparação.

Verifica-se que as alterações trazidas pelo novo instituto da responsabilidade civil do Estado ainda é tímida a respeito do dever de indenizar. Mas já foi grande avanço rumo ao estágio atual. Acolher a responsabilidade subjetiva implica impor 
que o lesado demonstre a existência de culpa ou dolo com liame subjetivo do evento danoso com o dano, representado pela intenção omissiva ou comissiva do agente. Assim, todos os requisitos inerentes à configuração da responsabilidade civil seriam necessários para responsabilizar o poder público nos danos causados, em face da conduta culposa do servidor. Caso não provasse esses elementos, sucumbia o direito da vítima em ver seus danos reparados.

Importante frisar que um dever imposto pela natureza jurídica da relação entre Estado e administrador (servidor público), pressupõe uma obrigação de agir (como ocorre nas carreiras policiais) ou de se omitir (como se observa nos segredos de Estado), colocando o agente público na posição de sujeito ativo na execução ou inexecução do evento. A conduta do agente, de certo, é uma emanação estatal, que só o fez compelido no dever assumido. Portanto, a responsabilidade pelos efeitos do evento lesivo não deveria recair diretamente na pessoa mandada a executar a ação ou omissão, pois há uma relação de subordinação, exceto em casos manifestamente ilegais e que deveria se abster. Kelsen (1998) traz a seguinte lição a respeito:

\footnotetext{
Se se aceita que apenas existe um dever jurídico de realizar uma determinada conduta quando a ordem jurídica torna a conduta oposta pressuposto de uma sanção, se é juridicamente obrigado a uma determinada conduta apenas o indivíduo que, pela sua conduta, não só pode cumprir o dever mas também - e especialmente - o pode violar, então, sujeito do dever atribuído ao Estado é o indivíduo que - como órgão do Estado - tem de, pela sua conduta, cumprir este dever e que, portanto, o pode violar através da sua conduta (KELSEN, 1998, p. 212).
}

Com razão assiste a Kelsen (1998), tendo em vista que a obrigação juridicamente imposta pelo Estado a seus administradores tem condão de provocar dano, ou seja, violar direito de outrem, de sorte que não representa a vontade do agente, mas da administração. Permitir que o servidor respondesse ilimitadamente pelos atos do Estado seria permitir o locupletamento sem causa do ente estatal, em detrimento da pessoa pública, muitas vezes desprovida de condições para suprir mais essa obrigação.

A culpa administrativa passou, assim, a ser substituída pela teoria do risco administrativo, atraindo a responsabilidade estatal pelo risco inerente às atividades desenvolvidas. A Constituição da República do Brasil de 1988 erigiu a responsabilidade civil do Estado, no $\S 6^{\circ}$, do artigo 37 , como objetiva na modalidade 
do risco administrativo, levando-se em consideração os riscos emanados de suas atividades. Assim, a responsabilidade objetiva exime o lesado de provar o elemento culposo da ação lesiva, que raramente é fácil de demonstrar, tornando inacessível restituição do equilíbrio desfeito pelo evento danoso, caso o ônus recaísse sobre a vítima. Nesse sentido, atualmente:

\begin{abstract}
A regra é a responsabilidade objetiva, fundada na teoria do risco administrativo, sempre que o dano for causado por agentes do Estado, nessa qualidade; sempre que houver relação de causa e efeito entre a atuação administrativa (comissiva ou por omissão específica) e o dano. Resta, todavia, espaço para a responsabilidade subjetiva (por omissão genérica) nos casos acima examinados - fatos de terceiros e fenômenos da Natureza -, determinando-se, então, a responsabilidade da Administração, com base na culpa anônima ou falta de serviço, seja porque este não funcionou, quando deveria normalmente funcionar, seja porque funcionou mal ou funcionou tardiamente (CAVALIERI FILHO, 2012, p. 287).
\end{abstract}

Portanto, a evolução legislativa permite perceber que o Estado se submete à regra da responsabilidade objetiva pelos atos praticados por seus agentes na qualidade do serviço público. A doutrina ainda entende que "a culpa in comittendo, como afirmamos, caracteriza-se por ato positivo do agente, enquanto a culpa in omittendo estampa-se no ato omissivo" (grifos do autor) (VENOSA, 2013, p. 33). Como visto, a regra atual é a responsabilidade objetiva, pois, "é de se concluir que a responsabilidade subjetiva do Estado não foi de todo banida da nossa ordem jurídica" (CAVALIERI FILHO, 2012, p. 287). Dessa forma, a responsabilidade subjetiva do Estado ainda estará a viger na ocasião de atos omissivos genéricos. Em considerações, os ensinamentos de Monteiro (1966):

Todos os intérpretes são unânimes em afirmar a integral adoção da responsabilidade objetiva pelo texto constitucional. Realmente, como observa Aguiar Dias, se a ação regressiva cabe quando tiver havido culpa do funcionário público, segue-se que não haverá ação regressiva quando inexistir culpa, embora o Estado continue a responder pelas consequências do evento lesivo (MONTEIRO, 1966, p. 66).

Contudo, haverá casos em que mesmo existindo dano por atividades lícitas o Estado não responderá subjetiva ou objetivamente por esses atos. Usa-se o exemplo indicado por Mello apud Mello (2009), consistente na hipótese de nivelamento de ruas por meio de asfalto. Assim, o autor explica que é possível que algumas casas fiquem abaixo ou acima do nível da rua, sem por isso ser indenizado. Pondera o autor ser "evidente que o conteúdo do poder atribuído ao Estado não 
consistia em sacrificar o direito de alguém" (MELLO, 2009, p. 985), portanto, nesse caso, não pode responder civilmente o Estado.

Por outro lado, os atos omissivos têm o condão de causar dano, assim como os atos comissivos. Ocorre que os eventos omissivos recebem roupagem diferenciada quanto à responsabilidade, pois, se trata de responsabilidade subjetiva para maior parte da doutrina e da jurisprudência. Assim, deve ser provado que o Estado se omitiu quando tinha o dever de agir, ou por falta de diligência necessária para evitar o dano (GONÇALVES, 2014, p. 207). Provado estes elementos da culpa, responde o Estado pelos danos advindos, pois, o Estado responderá "com base na culpa anônima ou falta de serviço, seja porque este não funcionou, quando deveria normalmente funcionar, seja porque funcionou mal ou funcionou tardiamente" (CAVALIERI FILHO, 2012, p. 287).

Importante notar que na responsabilidade objetiva com enfoque na teoria do risco administrativo a presunção de culpa é relativa ou mitigada. Vale dizer, a vítima do evento está desobrigada de provar o elemento culposo que gerou o dano. Mas, o Estado tem a prerrogativa de provar que não agiu com culpa, que não foi o autor do evento, que houve culpa concorrente ou exclusiva da vítima, provando excludentes de responsabilidade civil. Assim, a teoria do risco administrativo provoca a inversão do ônus probatório do elemento culpa que tem presunção juris tantum.

Ao revés, a doutrina discorre sobre a teoria do risco integral, que desde já se afirma que não foi adotada na responsabilidade civil brasileira do ente estatal. Por meio dessa teoria o Estado responderia por todos os danos causados independentemente de provar excludentes de responsabilidade. Ao lado da teoria da irresponsabilidade estatal, a teoria do risco integral seria o oposto, visto que na primeira o Estado se eximia por completo da responsabilidade pelos danos provocados, ao passo que na segunda o Estado teria de arcar com todos os prejuízos sem poder defender-se de seus atos. A teoria do risco integral foi amplamente refutada e não encontra aplicabilidade jurídica.

Portanto, a responsabilidade civil do Estado, em regra, é objetiva, na modalidade do risco administrativo, não se aplicando a teoria do risco integral. Admite-se, entretanto, a responsabilidade civil subjetiva pela omissão genérica. Até porque, "normalmente, a omissão por si só é irrelevante para a esfera jurídica. Somente pode ser responsabilizado por omissão o agente que estiver em situação jurídica que o obrigue a agir, a impedir um resultado" (VENOSA, 2013, p. 33-34), 
desde que seja provada a omissão ou a ação ou o dever de cuidado, elementos que configuram a culpa, ou como ensina Cavalieri Filho (2012), pela falta do serviço, pelo mau funcionamento, por funcionar de forma retardada ou não funcionar quando deveria.

De fato, a doutrina é divergente no que se refere à responsabilidade civil do Estado em situações de omissão. Mello (2009) entende que os atos omissivos geradores de danos engendrados pelo Estado, devem passar pelo crivo da responsabilidade civil subjetiva. O autor considera que precisa ser apurado se o ente estatal tinha o dever legal de evitar o dano. Cumpri ainda identificar se a omissão foi genérica ou específica. Se for genérica, a responsabilidade será subjetiva e se for específica, será objetiva.

Verifica-se a omissão genérica, sempre que não haja um dever jurídico do Estado em evitar o evento lesivo. Toma-se como exemplo os danos ocorridos por fenômenos da natureza e que não são previsíveis, como no caso de enchentes ocasionadas por intensas tempestades. Já na omissão específica há um dever legal do Estado em relação a evitar o evento danoso. Tem-se o exemplo de buraco em vias públicas de tráfego de veículos e pedestre, em que há dever estatal de mantêlas em perfeito estado de conservação para não causar acidentes. Vindo a faltar o serviço, responde o Estado objetivamente, não precisando ser discutido o elemento culpa (PORTELLA, 2008, on line). Da mesma forma, "em suma, a omissão específica, que faz emergir a responsabilidade objetiva da Administração Pública, pressupõe um dever específico do Estado, que o obrigue a agir para impedir o resultado danoso" (CAVALIERI FILHO, 2012, p. 268). Assim, desincumbiria o administrado do ônus desproporcional de provar a culpa do Estado pela omissão.

Ao revés, parte da doutrina entende de forma divergente quanto aos danos oriundo da omissão por parte do Estado:

Destarte, o Estado não seria, propriamente, o autor do dano. Sua omissão ou deficiência constituiria condição do dano, esta considerada como um evento que não ocorreu, mas se tivesse ocorrido seria capaz de impedir o resultado. Argumenta-se que não seria razoável o Estado responder objetivamente por um dano que, a rigor, não causou, mas apenas não atuou no sentido de impedi-lo. Segundo os defensores da teoria subjetiva, nas condutas omissivas o Estado responderá subjetivamente com fundamento na teoria da culpa do serviço, ou faute du service, como denominada pelos franceses. A culpa do serviço, falta do serviço ou, simplesmente, culpa anônima da administração estará caracterizada em três situações, a saber: a ausência do serviço, o serviço defeituoso ou o serviço demorado (grifos do autor) (GÓIS, 2015, on line). 
Alimentando a controvérsia "o art. $37, \S 6^{\circ}$, da Constituição, não se refere apenas à atividade comissiva do Estado; pelo contrário, a ação a que alude engloba tanto a conduta comissiva como omissiva" (CAVALIERI FILHO, 2012, p. 267). Igualmente, verificado que a omissão específica ocorreu, caberá ao lesado demonstrar o evento danoso, o dano e o nexo de causalidade, enfatizando que a omissão específica foi do atente público que tinha o dever de agir, por isso desonerar a vítima de provar que houve culpa.

De fato, a responsabilidade civil tem evoluído com o propósito mitigatório do poder estatal, sendo que sem prosperidade a teoria da irresponsabilidade, nem da culpa do serviço, hoje tal instituto tem enfoque no Estado Democrático de Direito. Garantir que o Estado se exima da responsabilidade por omissão específica, seria equipará-lo com a irresponsabilidade, compelindo o administrado com ônus ardente do probatório. Se à pessoa física impõem-se deveres, igualmente ao Estado como pessoa jurídica que é, o qual não pode alegar a simples omissão para livrar-se do dever de reparar danos, pois, a própria Constituição de 1988 elencou em seu artigo $37, \S 6^{\circ}$, que:

As pessoas jurídicas de direito público e as de direito privado prestadoras de serviços públicos responderão pelos danos que seus agentes, nessa qualidade, causarem a terceiros, assegurado o direito de regresso contra 0 responsável nos casos de dolo ou culpa (BRASIL, 1988, on line).

O texto constitucional é expresso no sentido do dever de reparar pelos danos que o Estado causar, pela natureza de seu serviço. Com isso, infere-se que caso ocorra omissão específica pode o Estado responder objetivamente. A tese de que isso representaria em considerar o Estado como segurador universal, conforme entendimento de Mello (2009), passa pelo seguinte entendimento de Tartuce (2014), segundo o qual, "deve ser imediatamente revista e repensada a aplicação da tese da responsabilidade civil do Estado por omissão e, portanto, subjetiva e dependente de culpa, nos casos de falta de segurança" (TARTUCE, 2014, p. 347). A proposta de revisão que o autor coloca está vinculada a teoria objetiva.

De toda forma, é necessária e urgente a pacificação desse entendimento. Tal uniformização se faz necessária tendo em vista a maior garantia constitucional jurisdicional, proporcionado pelo acesso à justiça e que tem amparo nos direitos 
humanos. Essas premissas serão objeto de estudo nos próximos tópicos.

\subsection{Omissões genérica e específica}

Como já analisado não só os atos comissivos podem gerar danos indenizáveis. Igualmente, a omissão também tem potencial de ferir direito alheio e ensejar a devida reparação. Parte da doutrina entende que a omissão do ente estatal não resultaria em responsabilidade, a não ser que esteja obrigado por lei ou convenção a evitar que o dano sobreviesse, conforme Gonçalves (2014). Defendese esse posicionamento justificando que do contrário o Estado figuraria como se fosse um segurador universal, sustentando a doutrina que o Estado não deu causa ao evento danoso, e por isso deve responder subjetivamente, porque tinha o dever jurídico de agir para impedir o dano, e se não tinha esse dever, não há responsabilidade, pois, "quando não houver esse dever jurídico de agir, a omissão não terá relevância causal e, consequentemente, nem jurídica" (CAVALIERI FILHO, 2012, p. 68). A esse respeito, Gonçalves (2014):

Pode-se, assim, afirmar que a jurisprudência tem entendido que a atividade administrativa a que alude 0 art. 37, § 6을 da Constituição Federal abrange tanto a conduta comissiva como a omissiva. No último caso, desde que a omissão seja a causa direta e imediata do dano (GONÇALVES, 2014, p. 183).

Branco (2012) entende que a prestação (como no caso a prestação jurisdicional) se traduz em ação positiva do Estado como forma de fazer alcançar a finalidade dos direitos e garantias, frisando por sua eficácia, nos seguintes termos:

A circunstância de os direitos a prestação traduzirem-se numa ação positiva do Estado confere-Ihes peculiaridades estruturais, em termos de níveis de densidade normativa, que os distinguem dos direitos de defesa, não somente quanto à finalidade, mas, igualmente, quanto ao seu modo de exercício e à eficácia (BRANCO, 2012, p. 344).

Similar entendimento se extrai de Mello (2009), ensinando que a responsabilidade civil do Estado não existirá em caso de omissão se a ele não for atribuído um dever legal de impedir o dano, e caso lhe imposto obrigação de agir e se omitiu, a responsabilidade seria na modalidade subjetiva. Por outro lado, Coelho (2012) entende que a omissão só gera responsabilidade subjetiva e desde que o 
agente tenha o dever de praticar o ato e se omitiu e que haja elemento capaz de demonstrar que a prática do ato teria o condão de evitar o dano:

\begin{abstract}
A omissão só gera responsabilidade civil subjetiva se presentes dois requisitos: a) o sujeito a quem se imputa a responsabilidade tinha o dever de praticar o ato omitido; e b) havia razoável expectativa (certeza ou grande probabilidade) de que a prática do ato impediria o dano (COELHO, 2012, p. 218).
\end{abstract}

Contudo, há de se distinguir a omissão genérica da específica para se aproximar da espécie ou natureza jurídica da responsabilidade estatal pelos atos omissivos. Na primeira tem-se que o Estado não está obrigado a agir para evitar o dano, por está o evento atrelado a algum fator da natureza que importe em caso fortuito ou força maior. Já a omissão específica se caracteriza pela falta do serviço quando havia um dever jurídico de agir para impedir o dano, vale dizer, "o serviço não funcionou, funcionou tardia ou ineficientemente" (MELLO, 2009, p. 1002-1003).

Pela primeira (omissão genérica) de fato o Estado não tem o dever de evitar o dano e por isso, justo que se tenha de apurar a culpa inerente ao evento para responsabilizá-lo civilmente. No entanto, pelo que parece, se o Estado tinha o dever de agir para evitar o dano, também é justo que seja responsabilizado, posto que se ele não pode ser um segurador universal, de certo também não pode perpetuar a impunidade. A omissão específica impunha um dever específico de agir e assim deve se comportar o ente estatal. Se o Estado se omite a ponto de causar dano a outrem, não pode ficar sem o dever de reparar.

Em contraposição a ilação destoante da teoria da responsabilidade subjetiva é o posicionamento de Cavalieri Filho (2012), explicando que dentro da distinção entre omissão genérica e específica, o autor se filia a esta por entender que nem sempre a responsabilidade estatal será subjetiva.

\begin{abstract}
Haverá omissão específica quando o Estado estiver na condição de garante (ou de guardião) e por omissão sua cria situação propícia para a ocorrência do evento em situação em que tinha o dever de agir para impedi-lo; a omissão estatal se erige em causa adequada de não se evitar o dano. Em outras palavras, a omissão específica pressupõe um dever especial de agir do Estado, que, se assim não o faz, a omissão é causa direta e imediata de não se impedir o resultado (CAVALIERI FILHO, 2012, p. 268).
\end{abstract}

Por oportuno, pondera-se que "à primeira vista parece que a responsabilidade objetiva do Estado é ampliada também para suas omissões" (VENOSA, 2013, p. 72). 
Portanto, a responsabilidade civil por omissão merece interpretação mitigatória. Vista a evolução da teoria geral da responsabilidade civil e do dever de indenizar do Estado, vinda da teoria da irresponsabilidade para aplicação da teoria do risco administrativo, é notório que essa evolução com o Estado Democrático de Direito, a tendência será adotar a responsabilidade civil objetiva do Estado nas omissões específicas.

\section{PRINCÍPIOS QUE NORTEIAM A RESPONSABILIDADE CIVIL DO ESTADO PELA DEMORA NA PRESTAÇÃO JURISDICIONAL}

Inicialmente cabe demonstrar que a responsabilidade civil do Estado pela demora ou morosidade na prestação jurisdicional é entendida por parte da doutrina como irresponsabilidade estatal. No início deste trabalho frisou-se que o princípio da irresponsabilidade do Estado está superado e que não encontra aplicabilidade prática na ordem jurídica atual. Monteiro (1966) naquela data consignou o seguinte a respeito:

Cumpre frisar apenas que este não responde pelos danos decorrentes de atos judiciais, quer provenientes da jurisdição graciosa, quer da jurisdição contenciosa. A irresponsabilidade do Estado por atos do judiciário é fatal corolário da autoridade da res judicata (grifos do autor) (MONTEIRO, 1966, p. 67-68).

$\mathrm{Na}$ atualidade, Branco (2012) traz entendimento em sentido contrário, interpretando que a abstenção do Estado quanto aos danos oriundos de seus atos é incompatível com os direitos fundamentais. Assim, extrai-se desse posicionamento que a responsabilidade civil do Estado está amarada no princípio do Estado Democrático de Direito e pelo princípio da compensação pecuniária pelo dano causado. Se aceita-se que o Estado se exima da responsabilidade de reparar por omissão ou por ter tardiamente prestado a tutela jurisdicional, estar-se a dizer que o Estado pode fazer o que bem entende na administração da coisa pública.

Fala-se isso porque o judiciário faz parte do Estado e administra coisa pública, a máquina judiciária. Do mesmo modo, tal imunidade blindaria o Estado e o exoneraria de promover melhorias no sistema da prestação jurisdicional, continuando a estagnar ou protelar a tomada de decisão e com isso causando danos para as partes que esperam por um deslinde mais célere da sua demanda. Tem-se 
como exemplo a ação de inventário, que por sua delonga morosidade na tomada de decisão sobre a partilha, os herdeiros chegam a falecer antes de terem a propriedade de suas cotas, o que Ihes possibilitaria dispô-las livremente. Há aí um evidente prejuízo, merecendo a devida reparação, em caso de morte do cotista, aos seus herdeiros.

Outro princípio norteador desse dever de indenizar por parte do Estado é a segurança jurídica. Alguns doutrinadores acreditam que essa segurança deve partir do poder judiciário, a exemplo de Gagliano e Pamplona Filho (2012).

Portanto, a responsabilidade civil do Estado está pautada em princípios constitucionais e balizadores do Estado democrático de direito. A segurança jurídica transmuta-se em um dos principais princípios que buscam demonstrar que o Estado garantidor tem de ser também um Estado protecionista como forma de garantir os direitos da dignidade da pessoa humana, por meio da razoável duração do processo e da aplicabilidade imediata dos direitos e garantias constitucionais. Quando esses princípios forem observados, notar-se-á que a lei cumpriu sua finalidade, preceituada na justiça e na paz social.

\subsection{Dignidade da Pessoa Humana}

No cotidiano, não raras vezes houve-se dizer que alguém não é digno, que não há dignidade em determinada pessoa. Em tempo de crise dizem que os políticos não são dignos de confiança. Mas, afinal, o que é dignidade? O que é ser digno? Segundo Ferreira (2004) dignidade é "1. Qualidade de digno. 2. Função, título etc., que confere posição graduada. 3. Honestidade, honra" (FERREIRA, 2004, p. 318). Até aqui parece que há sintonia entre esta definição e os dizeres da sociedade, sendo que ser digno significa "que merece respeito, ou que mostra correção, integridade" (FERREIRA, 2004, p. 318). No contexto jurídico dignidade tem conotação diferenciada, mas estará vinculada à conceituação empírica.

Segundo a doutrina, a dignidade importa em valoração da pessoa como humano de cunho internacional, pois, "o vértice maior da proteção global, regional e local dos direitos humanos é proteger as vítimas reais e potenciais de abusos de direitos, onde quer que se encontrem, celebrando a luta por dignidade, direitos e justiça" (PIOVESAN, 2013, p. 20). Vale dizer, a dignidade representa um avanço da sociedade contra as arbitrariedades governamentais. Quando o povo passa a dizer 
que os governantes não têm dignidade, quer se referir ao respeito de serem reconhecidos de onde estão. Quando o direito fala em dignidade, está se referindo a própria pessoa humana como sujeito de direito, Piovesan (2013) assim se refere:

\begin{abstract}
O direito à igualdade material, o direito à diferença e o direito ao reconhecimento de identidades integram a essência dos direitos humanos, em sua dupla vocação em prol da defesa da dignidade humana e da prevenção do sofrimento humano. A garantia da igualdade, da diferença e do reconhecimento de identidades é condição e pressuposto para o direito à autodeterminação, bem como para o direito ao pleno desenvolvimento das potencialidades humanas, transitando-se da igualdade abstrata e geral para um conceito plural de dignidades concretas (PIOVESAN, 2013, p. 161).
\end{abstract}

Verifica-se da doutrina e da jurisprudência que ainda não se chegou a uma conceituação precisa de dignidade no sentido jurídico. Tanto é que os dicionários de direito buscam não precisar uma resposta para esse termo. De igual modo ocorre com a atual Constituição Federal, que apenas afirma que a dignidade é um dos fundamentos da República Federativa do Brasil, em seu artigo 1ํㅜ, inciso III (BRASIL, 1988, on line).

De igual modo, Grau (2010), em seu voto na Arguição de Descumprimento de Preceito Fundamental 153 - ADPF-153 aduziu o seguinte sobre a dignidade da pessoa humana:

\begin{abstract}
A dignidade não tem preço. As coisas têm preço, as pessoas têm dignidade. A dignidade não tem preço, vale para todos quantos participam do humano. Estamos, todavia, em perigo quando alguém se arroga o direito de tomar o que pertence à dignidade da pessoa humana como um seu valor (valor de quem se arrogue a tanto). É que, então, o valor do humano assume forma na substância e medida de quem o afirme e o pretende impor na qualidade e quantidade em que o mensure. Então o valor da dignidade da pessoa humana já não será mais valor do humano, de todos quantos pertencem à humanidade, porém de quem o proclame conforme o seu critério particular. Estamos então em perigo, submissos à tirania dos valores (BRASIL, 2010, p. 23).
\end{abstract}

Percebe-se que não há falar em um valor para a pessoa humana, logo, fica inviável estabelecer qualquer conceituação generalizada. O que se sabe é que segundo Piovesan (2013), a dignidade está em harmonia com pessoa humana e, portanto, com direitos humanos. É assim, todo valor que se deva estabelecer de respeito a qualquer ser humano, deve-se levar em consideração a dignidade como valor do humano.

Em sintonia são as palavras de Lenza (2012): 
Sob essa perspectiva, especialmente diante do princípio da dignidade da pessoa humana, fundamento da República Federativa do Brasil e princípio matriz de todos os direitos fundamentais (art. 1.․, III, da CF/88), parece mais adequado, então, falar em um direito civil-constitucional, estudando o direito privado à luz das regras constitucionais e podendo, inclusive, em muitos casos, reconhecer a aplicação direta dos direitos fundamentais nas relações privadas (LENZA, 2012, p. 54).

Assim, diga-se, não só pelo princípio da dignidade ser um parâmetro aberto, a busca pelo direito pode e deve ser analisada pelo olhar da dignidade da pessoa humana. A espera, os desvios nas tratativas aos administrados também refletem na dignidade, passíveis de indenização consoante a Constituição matriz, inclusive frisando pela aplicação imediata dos direitos e garantias fundamentais, o que se inclui o processo em busca da satisfação jurisdicional, como serão abordados adiante. Assim:

Com a finalidade de garantir uma justiça plena, o Estado cria mecanismos que devem ser baseados em princípios, consolidados por meio de um procedimento histórico, para que pudesse existir a garantia de uma razoável duração ao processo (CURY, 2013, p. 26).

A dignidade da pessoa humana, sendo um parâmetro universal de valor da pessoa necessita de mecanismos que assegure tais valores. A demora na prestação jurisdicional fere esses paradigmas de valoração até atingir os valores sociais de direito fundamental. A justiça morosa importa em descrédito do poder judiciário e alimentação pelo retorna à vingança privada. Diante disso, salutar é a aplicação imediata dos direitos e garantias fundamentais, como será abordado mais adiante.

\subsection{Celeridade processual e a Emenda Constitucional no 45 de 2004}

A celeridade processual, juntamente com a dignidade da pessoa humana e a aplicação imediata dos direitos e garantias fundamentais, é mais um princípio que norteia a responsabilidade civil do Estado pela morosidade na prestação jurisdicional. Tal princípio teve inserção na ordem jurídica brasileira com a Emenda Constitucional $n^{\circ}$ 45, de 30 de dezembro de 2004 e prescreve que "a todos, no âmbito judicial e administrativo, são assegurados a razoável duração do processo e os meios que garantam a celeridade de sua tramitação" (BRASIL, 2004, on line). Interessante notar que este princípio foi inserido no título dos direitos e garantias 
fundamentais, e mais precisamente no rol do artigo $5^{\circ}$ da Constituição de 1988, deixando claro que se trata de um direito fundamental, e como já discorrido, também goza de aplicabilidade imediata, conforme $\S 1^{\circ}$, da Lei Maior.

A doutrina alega que esse princípio padece de aplicabilidade imediata porque não se tem uma definição a contento do que seria "razoável" para fins do deslinde processual. Por outro lado, Arruda (2013) afirma que a celeridade processual é um parâmetro de realização da justiça:

\begin{abstract}
Parece-nos bem evidente, portanto, que a inclusão do inciso LXXVIII neste artigo 5o marca a consolidação de uma nova etapa: uma fase em que o constituinte, já havendo assegurado o acesso à justiça, preocupa-se em garantir a qualidade do cumprimento dessa missão estatal. Aqui será interessante fazer um paralelo com a evolução que representou a edição da Emenda Constitucional 19, que incluiu a eficiência como princípio constitucional da administração pública. Se esta primeira reforma introduziu a eficiência como valor perseguido pelo administrador público, o inciso LXXVIII incorporou 0 valor eficiência temporal como parâmetro de consecução da justiça (ARRUDA, 2013, p. 1089).
\end{abstract}

Por outro viés, Venosa (2013) explica que a celeridade processual pode acarretar em uma análise muito sumária do caso concreto e resultar em decisão não muito condizente com a demanda, representando injustiça e flagrante afronta à segurança que se espera do processo e das decisões judiciais. Pontua ainda o autor que a morosidade acentuada também é fator não aceitável:

\begin{abstract}
A justiça muito rápida corre o risco de ser injusta; mas a justiça tardia é sempre injusta: o devedor e seus bens desaparece; a parte chega à velhice sem o reconhecimento definitivo de seu direito; desaparecem os vestígios do processo; a população descrê da justiça e do magistrado. Não é justa a decisão que tarda de oito a doze anos para atingir uma decisão final, da qual não caiba mais recurso, como ocorre com processos no Estado de São Paulo, não sendo muito diferente em outras regiões do País. Não se nega que existe gravame, inclusive elevado dano moral nesse retardamento da Justiça que por muitas vezes equivale à sua própria negação. Não é crível que a própria estrutura da União e da Justiça federal impeça que julgamentos importantes, de cunho alimentar previdenciário, dormitem por tantos anos nos escaninhos do Poder Judiciário, aguardando quiçá a morte dos interessados. A prestação jurisdicional tardia é instrumento dos maus pagadores, escudo de sua conduta ímproba (VENOSA, 2013, p. 111-112).
\end{abstract}

Assim, "a morosidade da Justiça, amplamente conhecida e criticada, apresenta-se como uma das grandes mazelas do Judiciário" (LENZA, 2014, p. 890). Visualizando questões práticas no concernente à celeridade processual, pode ser notado em processos como os criminais, de alimentos, previdenciários, trabalhistas 
que há necessidade de desfecho célere da demanda, pois em casos tais, a demora na prestação da tutela pode representar o falecimento do direito, quando não mais drástico, do próprio jurisdicionado. Nesse crível:

\begin{abstract}
A duração indefinida ou ilimitada do processo judicial afeta não apenas e de forma direta a ideia de proteção judicial efetiva, como compromete de modo decisivo a proteção da dignidade da pessoa humana, na medida em que permite a transformação do ser humano em objeto dos processos estatais (MENDES, 2012, p. 855).
\end{abstract}

Tácito (2012), explica que o Estado é instado a apaziguar litígios e que na ordem jurídica ele deve zelar pala paz social. Alega o autor que é preciso, com a dinâmica social, estabelecer paridade de condições perante a justiça.

Portanto, a celeridade processual se materializa como princípio norteador da responsabilidade civil do Estado pela demora na prestação jurisdicional. Tal princípio, dada sua grande relevância para a ordem jurídica, foi objeto da única emenda desde a entrada em vigor da Constituição em 1988, sendo acompanhado do princípio da aplicabilidade imediata, dentre o rol dos direitos e garantias fundamentais. Ao lado da oralidade e da instrumentalidade das formas, o princípio da celeridade é instrumento de trivial importância na consecução da prestação jurisdicional.

\title{
3.3 Aplicação imediata dos direitos e garantias fundamentais
}

A aplicação imediata dos direitos e garantias constitucionais, ilação do constitucionalismo moderno, estampado no $\S 1^{\circ}$, do artigo $5^{\circ}$, da Constituição de 1988 (BRASIL, 1988, on line), busca preservar a segurança jurídica e dar maior efetividade dos parâmetros trazidos pela Lei Maior. Além disso, preservam as condições de dignidade da pessoa humana, ao fazer com que os direitos básicos e elementares que norteiam a vida das pessoas recebam tratativas diferenciadas e céleres, como no caso, a busca pela satisfação jurisdicional, pelo acesso a justiça.

Branco (2012) considera que a emanação do $\S 1^{\circ}$, do artigo $5^{\circ}$, da Constituição (BRASIL, 1988, on line), não é norma programática e que o operador do direito (o magistrado em especial) deve dar aplicabilidade sem mesmo existir lei que o autorize, inclusive em face da lei, se esta se mostrar contrária aos direitos e garantias constitucionais. 
Os juízes podem e devem aplicar diretamente as normas constitucionais para resolver os casos sob a sua apreciação. Não é necessário que o legislador venha, antes, repetir ou esclarecer os termos da norma constitucional para que ela seja aplicada. O art. $5^{\circ}, \S 1^{\circ}$, da CF autoriza que os operadores do direito, mesmo à falta de comando legislativo, venham a concretizar os direitos fundamentais pela via interpretativa. Os juízes, mais do que isso, podem dar aplicação aos direitos fundamentais mesmo contra a lei, se ela não se conformar ao sentido constitucional daqueles (BRANCO, 2012, p. 332-333).

Observa-se que a norma constitucional de acesso à justiça e até da celeridade processual, que será objeto de estudo mais adiante, que são mecanismos para se evitar a morosidade processual, devem passar pela aplicabilidade imediata, tendo em vista que se trata de direito fundamental, pois, "o significado essencial dessa cláusula é ressaltar que as normas que definem direitos fundamentais são normas de caráter preceptivo, e não meramente programático" (BRANCO, 2012, p. 332), necessitando especial atenção do operador do direito.

Quanto ao termo aplicabilidade trazido pala Constituição de 1988, Silva (2012) entende que:

Significa qualidade do que é aplicável. No sentido jurídico, diz-se da norma que tem possibilidade de ser aplicada, isto é, da norma que tem capacidade de produzir efeitos jurídicos. Não se cogita de saber se ela produz efetivamente esses efeitos. Isso já seria uma perspectiva sociológica, e diz respeito à sua eficácia social (SILVA, 2012, p. 373).

Portanto, percebe-se que as normas garantidoras dos direitos e garantias fundamentais gozam da imperatividade e aplicabilidade imediata, devendo qualquer operador da ciência jurídica zelar pela eficácia dessas normas. Assim, indo o administrado em busca da tutela jurisdicional deve o poder judiciário aplica-la tal como previsto na lei regente e de acordo com o caso concreto. Contudo, Lenza (2012) interpreta essas garantias e afirma que deve haver um estudo da norma de eficácia plena e da limitada. Referido autor exemplifica o direito de greve dos servidores públicos (LENZA, 2012, p. 964), que é um direito fundamental, mas necessita de regulamentação para realmente efetivar-se, pois "há normas constitucionais, relativas a direitos fundamentais, que, evidentemente, não são autoaplicáveis. Carecem da interposição do legislador para que produzam todos os seus efeitos" (BRANCO, 2012, p. 334).

No entanto, não é o caso das normas que instituem os instrumentos da 
jurisdição, acesso à Justiça e direitos humanos da dignidade que são pleiteados na busca da satisfação da tutela jurisdicional. Nesse caso, a responsabilidade civil para que alcance o objetivo de reequilíbrio das relações jurídicas desfeitas, clama por efetividade dos ditames que norteiam os direitos e garantias fundamentais.

\section{A NATUREZA JURÍDICA DA RESPONSABILIDADE CIVIL DO ESTADO PELA DEMORA NA PRESTAÇÃO JURISDICIONAL}

Inicialmente, cabe esclarecer que na reparação civil estatal quem responde é a pessoa jurídica que o servidor está vinculado e não este, tendo em vista o princípio da impessoalidade dos atos administrativos, conforme ensinamentos de Di Pietro (2014). Com isso, o servidor pratica os atos visando o bem coletivo, a coisa pública. Por isso dizer que o agente responderá regressivamente, caso o Estado prove que 0 seu preposto agiu com culpa ou dolo.

A esse respeito, "a responsabilidade é atribuída à pessoa jurídica em razão do princípio da impessoalidade, em que o ato praticado pelo agente público não é dele, mas sim da pessoa jurídica a que ele pertence" (MARINELA, 2010, p. 881). Da mesma forma, haverá responsabilidade do Estado em caso de descentralização das atividades estatais, tendo em vista que o terceiro praticará os atos quando eram de responsabilidade do Estado. Nesse sentido, "a jurisprudência do STJ também admite a aplicação do art. $37, \S 6^{\circ}$, da CF para os funcionários terceirizados, tendo em Vista que a terceirização não exime de responsabilidade a prestadora do serviço" (MARINELA, 2010, p. 882).

Como já analisado, doutrinadores defendem que os atos omissivos do Estado implicam em reconhecer a responsabilidade subjetiva e em alguns casos até não haveria o dever de reparar por danos em decorrência de omissão, como no caso da omissão genérica.

No caso de atividades jurisdicionais, há doutrina que defende que em atos típicos da jurisdição, não haveria responsabilidade estatal, como no caso de sentenças ou decisões. Os estudiosos ainda defendem que em outros casos atípicos à atividade jurisdicional - haverá dever em indenizar caso os atos praticados resultem em dano a terceiros. Também é forte a doutrina dos que assemelham os atos jurisdicionais com a irresponsabilidade estatal, já discorrido alhures. São relevantes, nesse sentido, as palavras de Cavalieri Filho (2012) a 
respeito:

Tem-se dito que a irreparabilidade dos danos causados pelos atos judiciais é o último reduto da irresponsabilidade civil do Estado. O tema, na realidade, é complexo, o que ensejou variadas opiniões a seu respeito, que vão desde a total irresponsabilidade até a responsabilidade pela teoria do risco administrativo (CAVALIERI FILHO, 2012, p. 289).

Cavalieri Filho (2012) refuta com veemência a aplicabilidade da teoria da irresponsabilidade do Estado por atos jurisdicionais. Alega o autor que a independência funcional dos juízes não pode ser motivo para morosidade na prestação da tutela. Ora, o desfecho da demanda judicial ocorre por meio de uma decisão terminativa transitada em julgado e, por conseguinte, apenas é válida se proferida por um órgão devidamente investido na qualidade de magistrado, ou o que se diga de juiz natural. Se este deixa de sentenciar ou de praticar atos de impulso jurisdicional, a demanda tende a perpetuar-se no tempo, ocasionada pela morosidade.

Di Pietro (2014) enfatiza que um dos principais argumentos de defesa da não responsabilidade civil do Estado, no caso de atos jurisdicionais é a afirmativa de que os juízes não são funcionários. A autora afirma que esse fundamento é desprovido de plausibilidade, posto que na Constituição de 1988, em seu artigo 37, os magistrados foram incluídos na categoria de agentes públicos:

Quanto a não ser o juiz funcionário público, o argumento não é aceitável no direito brasileiro, em que ele ocupa cargo público criado por lei e se enquadra no conceito legal dessa categoria funcional. Ainda que se entenda ser ele agente político, é abrangido pela norma do artigo $37, \S 6^{\circ}$, da Constituição Federal, que emprega precisamente o vocábulo agente para abranger todas as categorias de pessoas que, a qualquer título, prestam serviços ao Estado (DI PIETRO, 2014, p. 736).

Venosa (2013) traz pertinentemente extensas considerações a respeito. Em suas lições o autor explica que já se encontra superada a teoria da irresponsabilidade estatal, pelo que os atos da administração têm o condão de implicar reparação por danos decorrentes das atividades do Estado. O autor introduz assertiva de que os juízes devem responder, nos limites do dolo e da culpa perpetrados pelos danos, inclusive por retardamento das decisões, pois aqui se situa a morosidade da tutela jurisdicional.

A doutrina é vasta no sentido de afastar a irresponsabilidade dos atos 
jurisdicionais, pois, "aceita-se, ainda, em bora muito estritamente, responsabilidade por atos jurisdicionais" (MELLO, 2009, p. 988). O Estado deve, segundo o autor, observar os fatores modificativos e evolutivos da responsabilidade, sendo que o referido instituto passou por profundas transformações, da inexistência de legislação própria para a irresponsabilidade até o estágio atual da responsabilidade objetiva pela aplicação do risco administrativo.

Como o objetivo principal deste trabalho é desvendar a natureza jurídica da responsabilidade civil do Estado pela demora na prestação jurisdicional, tem-se que seja louvável perceber que essa responsabilidade está ligada à omissão estatal no âmbito jurisdicional. Com isso, como já analisado, parece que tamanho dever de reparar se enquadra na responsabilidade civil por omissão específica. Tal afirmativa é possível com ilação constitucional de que o Estado deve proporcionar, conforme artigo 5, inciso LXXVIII da Constituição de 1988, a razoável duração do processo e os meios inerentes que garantam a celeridade processual, inclusive com sua aplicação imediata, consoante $\S 1^{\circ}$, deste referido artigo.

Percebe-se, então, que a responsabilidade pela demora na atividade jurisdicional desvincula-se das tratativas típicas da jurisdição. Ela está atrelada a uma garantia constitucional de celeridade, mais administrativa do que judicial. Desta feita, o aparelho jurisdicional estatal está se mostrando falho, ineficiente e omisso. Como a celeridade é uma garantia que repercute em uma ação positiva do Estado, em caso de morosidade, resta concluir que essa omissão seja específica, pois não agiu o ente estatal quando tinha o dever legal constitucional de intervir para evitar o prejuízo em decorrência da demora na prestação jurisdicional.

\section{CONCLUSÃO}

O acesso à justiça pela via jurisdicional hoje deve ser compreendido como forma de obtenção de uma decisão prolatada em tempo razoável e adequada para pacificar o conflito posto em juízo. Entretanto, se a tutela jurisdicional for prestada de forma intempestiva para preservação do bem da vida ou do direito ou se for injusta, além da ineficiência que causará ao direito, será mortal ao próprio princípio do acesso à justiça.

Portanto, robusta é a argumentação para concluir que a natureza jurídica do Estado pela demora na prestação jurisdicional seja objetiva, com fundamento na 
omissão específica. O parâmetro constitucional deixa claro que é dever do Estado garantir a razoável duração do processo e os meios que garantam a celeridade processual. Nesse caso não se discute a autonomia do magistrado, sendo que a morosidade processual é um repúdio constitucional que deve ser observada por todos os agentes jurisdicionais de garantia aos direitos fundamentais.

Quando essa garantia não é observada por parte do Estado jurisdicional, temse flagrante afronta aos direitos fundamentais, ensejadores dos efeitos da responsabilidade civil estatal. Em que pese seja a jurisprudência pátria divergente nesse sentido, mantemos esse posicionamento por entendermos superada a irresponsabilidade estatal e que de fato, a omissão a um dever específico, atrai a responsabilidade direta do omitente, que se agisse poderia impedir o resultado danoso.

\section{REFERÊNCIAS}

ARRUDA, Samuel Miranda. Comentários ao art. 5ㅜ, inciso LXXVIII. In: CANOTILHO, José Joaquim Gomes; MENDES, Gilmar Ferreira; SARLET, Ingo Wolfgang;

STRECK, Lenio Luiz. (Coords.). Comentários à Constituição do Brasil. São Paulo: Saraiva/Almedina, 2013, p. 1088-1099.

BARBOSA, Rui. Oração aos moços. 5. ed. Rio de Janeiro: Fundação Casa de Rui Barbosa, 1997.

BRANCO, Paulo Gustavo Gonet. Teoria geral dos direitos fundamentais. In: MENDES, Gilmar Ferreira; BRANCO, Paulo Gustavo Gonet. Curso de direito constitucional. 7. ed. São Paulo: Saraiva, 2012.

BRASIL. Constituição (1824). Constituição política do Império do Brasil de 25 de março de 1824. Disponível em:

<http://www.planalto.gov.br/ccivil_03/constituicao/constituicao24.htm>. Acesso em: 10 fev. 2015.

\section{. Constituição (1988). Constituição da república federativa do Brasil de}

1988. Disponível em:

<http://www.planalto.gov.br/ccivil_03/Constituicao/Constituicao.htm>. Acesso em: 16 fev. 2015.

. Constituição (1988). Emenda constitucional no 45, de 30 de dezembro de 2004. Altera dispositivos dos arts. 5으. 36, 52, 92, 93, 95, 98, 99, 102, 103, 104, 105, 107, 109, 111, 112, 114, 115, 125, 126, 127, 128, 129, 134 e 168 da Constituição Federal, e acrescenta os arts. 103-A, 103-B, 111-A e 130-A, e dá outras providências. Diário Oficial da União, Brasília, 31 dez. 2004. 
. Lei no 10.406, de 10 de janeiro de 2002. Institui o Código Civil. Disponível em: <http://www.planalto.gov.br/ccivil_03/leis/2002/l10406.htm>. Acesso em: 16 fev. 2015.

. Supremo Tribunal Federal. ADPF 153: arguição de descumprimento de preceito fundamental. Relator Eros Grau. Julgamento em: 29 abr. 2010. Tribunal Pleno. Publicado em: 06 ago. 2010.

CAVALIERI FILHO, Sergio. Programa de responsabilidade civil. 10. ed. São Paulo: Atlas, 2012.

COELHO, Fábio Ulhoa. Curso de direito civil: obrigações - responsabilidade civil. 5. ed. São Paulo: Saraiva, 2012.

CURY, Paula Itabaiana Nicolau. Responsabilidade do Estado pela Demora na Prestação da Tutela Jurisdicional. Revista da EMERJ: escola da magistratura do Estado do Rio de Janeiro. Disponível em:

<http://www.emerj.tjrj.jus.br/paginas/trabalhos_conclusao/1semestre2013/trabalhos 12013/PaulaltabaianaNicolauCury.pdf>. Acesso em: 12 mar. 2015.

DI PIETRO, Maria Sylvia Zanella. Direito administrativo. 23. ed. São Paulo: Atlas, 2010.

. Direito administrativo. 27. ed. São Paulo: Atlas, 2014.

FERREIRA, Aurélio Buarque de Holanda. Miniaurélio: o minidicionário da língua portuguesa. ANJOS, Margarida dos; FERREIRA, Marina Baird (Coords). 6. ed. Curitiba: Positivo, 2004.

GAGLIANO, Pablo Stolze; PAMPLONA FILHO, Rodolfo. Novo curso de direito civil: responsabilidade civil. 10. ed. São Paulo: Saraiva, 2012.

GÓIS, Ewerton Marcus de Oliveira. A responsabilidade civil do estado por atos omissivos e o atual entendimento do supremo tribunal federal. Disponível em: <http://www.mp.go.gov.br/portalweb/hp/10/docs/3_-

_a_responsabilidade_civil_do_estado_por_atos_omissivos_e_o_atual_entendimento _do_supremo_tribunal_federal.pdf>. Acesso em: 15 mar. $201 \overline{5}$.

GONÇALVES, Carlos Roberto. Responsabilidade civil. 15. ed. São Paulo: Saraiva, 2014.

KELSEN, Hans. Teoria pura do direito. [tradução João Baptista Machado]. 6. ed. São Paulo: Martins Fontes, 1998.

LENZA, Pedro. Direito constitucional esquematizado. 16. ed. São Paulo: Saraiva, 2012.

Direito constitucional esquematizado. 18. ed. São Paulo: Saraiva, 2014.

MARINELA, Fernanda. Direito administrativo. 4. ed. Niterói: Impetus, 2010. 
MEIRELLES, Hely Lopes. Direito administrativo brasileiro. 36. ed. São Paulo: Malheiros Editores, 2010.

MELLO, Celso Antônio Bandeira de. Curso de direito administrativo. 26. ed. São Paulo: Malheiros Editores, 2009.

MENDES, Gilmar Ferreira. Direitos fundamentais de caráter judicial e garantias constitucionais do processo. In: MENDES, Gilmar Ferreira; BRANCO, Paulo Gustavo Gonet. Curso de direito constitucional. 7. ed. São Paulo: Saraiva, 2012.

MONTEIRO, Washington de Barros. Curso de direito civil: parte geral. São Paulo: Saraiva, 1966.

PIOVESAN, Flávia. Direitos humanos e o direito constitucional internacional. 14. ed. São Paulo: Saraiva, 2013.

PORTELLA, Simone de Sá. A responsabilidade civil do Estado por omissão. Âmbito Jurídico, Rio Grande, XI, n. 59, nov. 2008.

SILVA, José Afonso da. Aplicabilidade das Normas Constitucionais. In: MARTINS, Ives Gandra da Silva; MENDES, Gilmar Ferreira; NASCIMENTO, Carlos Valder do (coordenadores). Tratado de direito constitucional. 2. ed. São Paulo: Saraiva, 2012.

TÁCITO, Caio. Constituições brasileiras. 3. ed. Brasília: Senado Federal, Subsecretaria de Edições Técnicas, 2012.

TARTUCE, Flávio. Direito civil: direito das obrigações e responsabilidade civil. 9. ed. Rio de Janeiro: Forense; São Paulo: Método, 2014.

VENOSA, Sílvio de Salvo. Direito civil: parte geral. 13. ed. São Paulo: Atlas, 2013. . Direito civil: responsabilidade civil. 13. ed. São Paulo: Atlas, 2013. 